\title{
O mito de Eros e Thanatos na obra de Mário de Sá-Carneiro
}

\author{
Eric Beuttenmüller ${ }^{1}$
}

\begin{abstract}
This article intends to show the presence of the myth of Eros e Thanatos in Mario de Sá-Carneiro's lyric and narratives. Through the reading of some poems and passages of his narratives, it tries to verify in which ways this myth appears, and how its study may be important in the interpretation of his literary texts and in the formation of his vision of the world.

Keywords: Myth; archetype; Portuguese Literature; Mário de Sá-Carneiro.

Resumo: Este artigo pretende mostrar a presença do mito de Eros e Thanatos na lírica e nas narrativas de Mário de Sá-Carneiro. A partir da leitura de alguns poemas e de trechos de suas narrativas procura-se verificar de que forma este mito está presente, e como o seu estudo pode ser importante na interpretação de seus textos literários e na construção de uma visão de mundo do autor.
\end{abstract}

Palavras-chave: Mito; arquétipo; Literatura Portuguesa; Mário de Sá-Carneiro.

Introdução

No primeiro número da revista Orpheu há dois poemas com o título "Salomé", sendo um de Mário de Sá-Carneiro e outro de Alfredo Guisado. Ambos fazem referência a essa figura histórica, seguindo a tradição literária portuguesa em que se encontram diversas referências a ela. Segundo e estudo de Paula Morão (2001), desde o final do século XIX até o Modernismo português há diversas referências a Salomé e a outras figuras femininas de diversas matrizes e fontes culturais que representam o feminino perverso, ou ainda a figura da femme fatale. Percebe-se então a relevante presença do mito de Salomé neste período da Literatura Portuguesa. Mário de Sá-Carneiro foi um artista de transição, de um momento da Literatura ligado ao Simbolismo e ao Decadentismo para o Modernismo, e em sua obra há várias referências a este mito.

Sobre a obra lírica de Mário de Sá-Carneiro temos um importante estudo realizado por Fernando Paixão ${ }^{2}$. Segundo ele, o mito que melhor simboliza a sua obra lírica seria o de Narciso, que pela poesia pratica o próprio sacrifício, como visão a ser oferecida aos leitores. Ele afirma que existem certos "motivos" universais da vivência humana, e que podem ser encontrados em lendas da mitologia clássica. Assim, segundo Paixão (2003) a mitologia pode trazer alguns elementos importantes na interpretação de um texto literário, e na construção de uma visão de mundo a partir da Literatura, já que, como ele afirma, o mundo mítico e o da linguagem possuem estruturas determinadas pelos mesmos "motivos". Estes podem ser chamados de mitos e arquétipos, e segundo vários estudiosos eles aparecem nos textos literários dos mais diversos autores.

1 Doutor em Letras pela Universidade de São Paulo - USP. Professor da Faculdade Piaget.

2 O estudo referido foi transformado em livro, Narciso em sacrificio, Cotia: Ateliê Editorial, 2003. 
Alguns estudiosos como E. M. Meletinski fizeram a conexão entre o termo "arquétipo" dentro da Psicanálise e o mesmo termo dentro da Teoria Literária. Meletinski (1999) afirma que o termo "arquétipo" foi introduzido por Jung, sendo que posteriormente outros pesquisadores de várias áreas se debruçaram sobre esse assunto, como Joseph Campbell, E. Neumann, entre outros. Meletinski continua a dissertar e explica as sutilezas da diferença entre as definições de arquétipo entre os vários estudiosos do assunto. Jung (1964) explica, ao considerar sobre os sonhos, que existem elementos sonhados que não pertencem ao universo de experiências pessoais de quem sonhou, não são elementos individuais. Esses elementos são chamados arquétipos.

O arquétipo é uma tendência para formar estas mesmas representações de um motivo [...] sem perder a sua configuração original. Existem, por exemplo, muitas representações do motivo irmãos inimigos, mas o motivo em si conserva-se o mesmo. [...] A sua origem não é conhecida; e eles se repetem em qualquer época e em qualquer lugar do mundo. (JUNG, 1964, p. 67, 69).

Notamos que os arquétipos são elementos, são motivos universais que estão presentes na mente de todos os homens, mesmo que eles não saibam. $\mathrm{O}$ arquétipo tem origem no inconsciente e por isso muitas vezes não são reconhecidos como tal por quem o produz, uma vez que não temos controle sobre o inconsciente. Por isso, como afirma Frye (2000) muitos artistas os utilizam de forma inconsciente. Eles são modelos básicos, mas que, como diz Jung, podem sofrer algumas modificações dentro do enredo em que aparecem. Contudo, isso ocorre sem que a formatação primária seja alterada, ou seja, podem ocorrer leves variações do tema subjacente a ele, mas a mensagem fundamental que o arquétipo original encerra vai ser mantida.

E. M. Meletinski afirma que existem "[...] elementos temáticos permanentes que acabam se constituindo em unidades como que de uma 'linguagem temática' da literatura universal" (MELETINSKI, 1999, p. 19). Ele chama esses "motivos" que se repetem ao longo da história da Literatura de arquétipos temáticos, que se caracterizam por uma excepcional uniformidade. São esquemas narrativos que apesar de apresentarem variações ao longo do tempo, na verdade, não passam de transformações criativas daqueles arquétipos originais. Northrop Frye (2000) nos mostra ainda que cada autor tem uma mitologia particular, ou seja, uma repetição de elementos temáticos, da qual em grande parte ele mesmo não é consciente. Ele afirma que a criação literária é feita pelo desejo consciente do artista de construir o seu texto, mas que existem esses elementos, os mitos e arquétipos, que estão presente em sua obra, tenha ele consciência disso ou não. Sendo assim, mesmo com toda a preocupação de Sá-Carneiro de seguir as vanguardas, principalmente as idealizadas por Fernando Pessoa, como o Sensacionismo, o Paulismo e o Interseccionismo, há elementos que aparecem de forma involuntária, como mitos e arquétipos, cuja escolha pode revelar bastante sobre a sua visão de mundo.

Paixão (2003) faz referência a Ernst Cassirer, um importante estudioso das relações entre mito e linguagem, e sobre a similaridade entre a construção da metáfora e do mito. Essa semelhança revela que o mito, assim como a metáfora, pode revelar sentidos dentro do texto literário, pode expandir significados latentes. Para se fazer uma analogia, assim como a metáfora revela significados conotativos, e que podem enriquecer a leitura do texto literário ${ }^{3}, \mathrm{o}$ mito também pode revelar sentidos, formas de ver a realidade sob a ótica de um autor.

3 É tão relevante o estudo da metáfora nos textos literários, que Paul Ricoeur dedicou a ela um estudo sob o ponto de vista da Hermenêutica. Uma das principais obras com esse enfoque é Metáfora viva. São Paulo: Edições Loyola, 2000. 
A partir do estudo de Cassirer (2009), fica clara a relação entre mito e linguagem, sendo que ambos partem de um pensar metafórico, e fica clara também a importância do mito dentro do fenômeno da linguagem. Ernst Cassirer mostra como os conceitos formadores de ambos são distintos dos conceitos cognoscitivos elaborados pelas ciências. $\mathrm{Ou}$ seja, a consciência linguística e a mítica são extremamente similares entre si, e completamente diferentes da consciência científica. O que ele quer dizer é que, tanto o processo de formação da linguagem humana, quanto o processo de formação do mito, se originara de uma forma de pensar metafórica. A linguagem foi se formando a partir de associações metafóricas que os primeiros seres humanos fizeram, e o mesmo ocorreu com o mito. Mais ainda, segundo ele

[...] a linguagem e o mito se acham originalmente em correlação indissolúvel, da qual só aos poucos cada um vai se desprendendo como membro independente. Ambos são ramos diversos dom mesmo impulso de informação simbólica, que brota de um mesmo ato fundamental e da elaboração espiritual, da concentração e elevação da simples percepção sensorial. [...] ambos constituem a resolução de uma tensão interna, a representação de moções e comoções anímicas em determinadas formações e conformações objetivas. (CASSIRER, 2009, p. 106)

Assim sendo, tanto o mito quanto a linguagem são representações exteriores, são materializações de impulsos anímicos, de sensações ou conceitos internos que a humanidade foi aprendendo a exteriorizar. E esse processo é puramente metafórico, pois se trata de exprimir externamente algo que está alojado dentro do ser. Essa relação entre o que se sente e o que se comunica para um interlocutor, entre o que está animicamente contido no ser e o que se exterioriza é um processo metafórico, tanto para o mito quanto para a linguagem. Cassirer mostra ainda que a arte também tem forte ligação com o mito: "Mito, linguagem e arte formam inicialmente uma unidade concreta ainda indivisa," (CASSIRER, 2009, p. 116). Pouco a pouco, com o tempo, esta união vai se desfazendo, e cada elemento dessa tríade ganha corpo e se torna uma entidade separada e independente. Assim, a linguagem foi se afastando desse processo metafórico, e as palavras passaram a ser cada vez mais signos conceituais, e não metáforas de moções e comoções anímicas do ser humano: "É que a linguagem não pertence exclusivamente ao reino do mito; nela opera, desde as origens, outra força, o poder do logos" (CASSIRER, 2009, p. 114).

Tudo isso mostra a relevância do estudo do mito dentro de uma obra literária. Se o mito, na sua origem, assim como a linguagem, é a exteriorização de sentimentos, sensações e conceitos de um ser, ele pode ser revelador da forma como um escritor - mesmo que historicamente muito afastado das origens do mito - se posiciona perante o mundo, e na forma como ele o concebe dentro de uma obra literária, ou dentro do conjunto de seus textos literários. O mito de Eros e Thanatos pode ser encontrado tanto obra lírica quanto na prosa de Mário de Sá-Carneiro, sendo que existe um diálogo entre ambas, na medida em que vários temas encontrados nos seus poemas são observados também em suas narrativas.

\section{Eros e Thanatos na lírica de Mário de Sá-Carneiro}

Voltando a falar do poema "Salomé” de Sá-Carneiro, publicado no primeiro número de Orpheu, percebemos que a imagem da dançarina sensual e perversa nos remete a outro mito com forte presença na Literatura: o de Eros e Thanatos, como veremos a seguir: 
Salomé

Insônia roxa. A luz a virgular-se em medo, Luz morta de luar, mais Alma do que lua... Ela dança, ela range. A carne, álcool de nua, Alastra-se pra mim num espasmo de segredo...

Tudo é capricho ao seu redor, em sombras fátuas...

$\mathrm{O}$ aroma endoideceu, upou-se em cor, quebrou...

Tenho frio...Alabastro!...A minh'alma parou...

E o seu corpo resvala a projetar estátuas...

Ela chama-me em Íris. Nimba-se a perder-me, Golfa-me os seios nus, ecoa-me em quebranto... Timbres, elmos, punhais...A doida quer morrer-me:

Mordoura-me a chorar - há sexos no seu pranto... Ergo-me em som, oscilo, e parto, e vou arder-me Na boca imperial que humanizou um Santo...

(SÁ-CARNEIRO, 2004, p. 39)

Como afirmou Fernando Cabral Martins (1994), é forte a presença do mito de Eros e Thanatos neste poema, ou seja, ao mesmo tempo existem desejo e morte no ambiente construído pelo poeta. Mas, como é comum na obra lírica de Sá-Carneiro, os temas giram em torno de um "eu", da questão da identidade, e a referência à figura histórica serve mais para construir imagens interiores do eu-lírico do que para se referir a algo externo a ele. O soneto é, assim, uma experiência onírica em que a referência a fatores externos serve para construir uma auto-imagem.

A expressão inicial, "Insônia roxa" como afirma Dieter Woll (1968) já é uma metáfora de sonho e está associada com sensações eróticas, que dialogam com outras sensações da mesma natureza despertadas pela dança, pela carne, pelo "álcool de nua". Cria-se, ao longo do poema uma atmosfera sinestésica de cores, sons, aromas, relacionados, também, ao efeito que a dança da bailarina Salomé cria. $\mathrm{O}$ verso "O aroma endoideceu, upou-se em cor, quebrou..." mostra bem o efeito sinestésico causado pela dança, que mais sugere que descreve objetivamente o cenário, o ambiente que se cria. Aliás, as sinestesias são bastante comuns em sua obra, e ajudam a criar um ambiente bastante sensorial e, neste caso, onírico. Segundo Fernando Paixão: “[...] Sá-Carneiro investiu na criação de um conturbado universo de cor, movimento, luz e som - resultando numa expressão de rica plasticidade." (PAIXÃO, 2003, p. 19)

O primeiro terceto mostra bem a mistura de desejo e morte, enquanto ela "Golfa-me o seios nus", aparecem imagens que despertam a sensação da morte, "Timbres, elmos, punhais...". Logo após, um uso peculiar do verbo morrer, que passa a ser transitivo direto, causando um sentido incomum: "A doida quer morrer-me", que parecer significar que o sujeito que mata é o mesmo que morre, ou seja, ele e a dançarina fazem parte de uma mesma pessoa. Ele não está assistindo a uma mulher "real" que está dançando, mas Salomé representa, neste poema, uma parte de si mesmo, da identidade fragmentada do eu-lírico.

Segundo Martins (1994) a ligação entre Eros e Thanatos na visão da psicanálise ligase ao corpo instintivo. Em Sá-Carneiro, a morte de Salomé representa a impossibilidade da posse da mulher desejada. Essa noção da posse manifestada como impossível, e muitas 
vezes pela proibição moral, dialoga com o próprio mito original, uma vez que Herodes nutria um forte desejo por Salomé, mas não poderia realizá-lo porque ela era sua sobrinha. Essa tensão sexual, esse desejo proibido acabam sendo elementos fundamentais no desenvolvimento do mito, em que o corpo feminino que encanta e seduz acaba por anular a racionalidade do homem, que se vê compelido a praticar uma infração legal ou moral. Por isso essa imagem da mulher como fatal, como uma figura negativa, tornou-se conhecida como feminino perverso. Essa visão da mulher, no caso de Sá-Carneiro também tem origens no Decadentismo que, junto com o Simbolismo exerceu forte influência em grande parte de sua obra. Segundo José Carlos Seabra Pereira, no Decadentismo, diferentemente do Romantismo, “ [...] não há qualquer correspondência entre o amor humano e o divino, nem à mulher é atribuída a função ética de elevação espiritual do homem, [...]” (PEREIRA, 1975, p. 40). No Decadentismo é comum a representação de relações amorosas ligadas a referências negativas, à anomalia erótica ou à aberração sexual, e frequentemente à perdição das personagens.

Outro poema relacionado ao mito de Salomé que também foi publicado no primeiro número de Orpheu foi “Certa voz na noite, ruivamente...", que também traz essa imagem negativa de seu lado feminino, ligada a Eros e Thanatos. Novamente, em um ambiente que mistura desejo e morte, há uma voz "opiada": "Que eu lembro não sei de onde - a voz de uma Princesa / Bailando meio nua entre clarões de espada" (SÁ-CARNEIRO, 1995, p. 81). Outros versos mostram a relação entre sexualidade e depravação, revelando a presença de uma femme fatale: "Leonina, ela arremessa a carne arroxeada; / E bêbada de Si, arfante de Beleza, / Acera os seios nus, descobre o sexo... Reza / O espasmo que a estrebucha em Alma copulada..." (SÁ-CARNEIRO, 1995, p. 81). Essa figura feminina é associada à devassidão, à corrupção do desejo sexual e, finalmente a uma sensação de perdição: "E nessa voz-Estátua, ah! nessa voz total, / É que eu sonho esvair-me em vícios de marfim..." (SÁ-CARNEIRO, 2004, p. 39).

O mito de Eros e Thanatos denota uma forma pessimista de encarar o amor, transformando-o em um sentimento que não pode ser consumado, não pode ser realizado de forma autêntica. Assim, a saída para o amor, em Sá-Carneiro, é a morte. Segundo Maria da Graça Carpinteiro:

Desde as primeiras páginas de Sá-Carneiro a morte vem como solução única consumir em si uma ânsia de impossível, dar um remate a um estado de tensão insustentável, cortar o nó dum conjunto de problemas que criam um ambiente de beco sem saída. $\mathrm{O}$ amor se resolve em morte - resolver-se-á sempre em morte. (CARPINTEIRO, 1960, p. 10).

Além de ser resolvido em morte, o amor em Sá-Carneiro está intimamente ligado a figura arquetípica da femme fatale, a partir do mito de Salomé, que é bastante comum na literatura portuguesa. Segundo Morão (2001), a figura histórica e bíblica de Salomé acaba se fundindo com outras mulheres famosas, para formar o arquétipo da femme fatale, mas o mito ficou conhecido como o de Salomé. Assim, a partir da junção da figura de Salomé com outras personagens históricas e bíblicas como Eva, Judite, Cleópatra, Dalila, Madalena, além de outras vindas da mitologia greco-latina como Medusa, a esfinge, Medeia e Vênus, forma-se o arquétipo da femme fatale, como uma mulher em que o amor e a morte estão ligados.

Paula Morão (2001) também chama a atenção para o fato de que o mito de Salomé revela uma concepção do papel da mulher na sociedade, que os escritores acabam transmitindo de forma inconsciente para as suas obras. Ela elenca uma série de autores e obras 


\section{Conexão Letras}

em que isso acontece, inclusive Mário de Sá-Carneiro. Isso revela uma inquietação presente nas obras - a mesma de João, no mito original, que está dividido entre a santidade e o mal, representado pelo corpo erotizado de Salomé e a de Herodes, que já comentamos - gerada pelas várias vertentes do feminino perverso, mitificada na exibição do corpo, na sedução castradora de uma femme fatale. Por trás disso, estão a misoginia e o enigma do eterno feminino, que afeta os autores, predominantemente do sexo masculino, em uma época em que o papel da mulher era bastante secundário em relação ao homem.

Enfim, tenha-se presente que, se estes mitos correspondem a um modismo, está também por detrás deles uma questão cultural e de mentalidade: a concepção dos papéis da mulher que subjaz à misoginia, ao diabolismo e à femme fatale, frígida e impiedosa, insere-se num quadro de valores em que a ordem masculina impõe as suas leis, tolerando um mundo marginal cuja existência desconhece ou simula desconhecer. (MORÃO, 2001, p. 38)

Morão nos mostra que no imaginário masculino as mulheres na Europa de fim de século XIX, estão divididas entre as castas esposas burguesas e as "mulheres de prazer", que se dividem entre cortesãs sofisticadas e prostitutas que atuam nas ruas, teatros, entre outros ambientes. Isso mostra que existe uma dicotomia em relação ao amor, na visão dos homens da época, inclusive em Sá-Carneiro. Por isso, tanto no caso da esposa casta, quanto da cortesã, há pouca maturidade emocional masculina, porque a forma como a mulher é vista e retratada obedece a pólos opostos - não há o desenvolvimento sadio de uma relação emocional satisfatória e positiva com a figura feminina, o que acaba sendo retratado nas artes plásticas e na Literatura.

Este ponto levantado por Morão é bastante relevante, uma vez que é revelador das escolhas de Sá-Carneiro na sua lírica e nas suas narrativas, e mostra que sua visão de mundo, neste ponto, é muito parecida com a da maioria dos homens do século XIX. Talvez ele tenha sido levado por essa concepção masculina do papel da mulher, que existia em sua época, e inconscientemente atribui pouca importância às figuras femininas em suas narrativas, como veremos. De qualquer forma, a presença desse mito, como mostrou Paula Morão, ajuda a justificar a menor importância das personagens femininas nas narrativas de Mário de Sá-Carneiro, uma vez que reflete o papel social da mulher na época. E na sua lírica, a mulher é frequentemente retratada como uma femme fatale.

Há outros poemas de Sá-Carneiro em que aparece a figura feminina associada a Eros e Thanatos, ao feminino perverso, como "Bárbaro" e "Feminina". A seguir, este último de ambientação mais moderna:

Feminina

Eu queria ser mulher pra me poder estender

Ao lado dos meus amigos, nas banquettes dos Cafés.

Eu queria ser mulher para poder estender

Pó-de-arroz pelo meu rosto, diante de todos, nos Cafés.

Eu queria ser mulher pra não ter que pensar na vida E conhecer muitos velhos a quem pedisse dinheiro Eu queria ser mulher para passar o dia inteiro A falar de modas e a fazer "potins" - muito entretida.

Eu queria ser mulher para mexer nos meus seios E aguçá-los ao espelho, antes de me deitar- 
$\mathrm{Eu}$ queria ser mulher pra que me fossem bem estes enleios,

Que num homem, francamente, não se podem desculpar.

Eu queria ser mulher para ter muitos amantes

E enganá-los a todos - mesmo ao predileto -

Como eu gostaria de enganar o meu amante loiro, o mais esbelto,

Com um rapaz gordo e feio, de modos extravagantes...

Eu queria ser mulher para excitar quem me olhasse,

Eu queria ser mulher pra poder me recusar...

(SÁ-CARNEIRO, 2004, p, 95)

Logo no primeiro verso, notamos claramente uma referência ao seu lado feminino: "Eu queria ser mulher", que se repetirá ao longo do poema. Talvez sendo mulher ele se sentisse mais à vontade, pudesse se "estender [...] / nas banquettes dos Cafés", ou passar pó-de-arroz na frente das outras pessoas, sem se sentir angustiado, como normalmente se sentia em público. $\mathrm{O}$ ato de se maquiar na frente dos outros, pode representar uma atitude afirmativa, de autoconfiança, que não costumava ter normalmente. Também, sendo mulher, se sentiria mais à vontade com seus próprios amigos, se sentiria mais confiante, não quebraria as coisas com seus modos desajeitados, nem teria que mentir para eles, criando histórias fantasiosas. O eu-lírico mostra como seria a sua vida na nova condição: fútil, não tendo pensamentos ou preocupações, e explorando os homens mais velhos. Uma existência vazia e superficial, que leva os homens à perdição, como faz uma femme fatale.

O eu-lírico desejava ser uma mulher que "brinca" com seus pretendentes, "E enganá-los a todos", e os encara como peças de um jogo. Parece que o "rapaz gordo e fio, de modos extravagantes" é uma imagem dele mesmo, que serviria apenas para enganar e, de certa forma, humilhar o seu amante loiro e esbelto. Ninguém escaparia de ser um peão no tabuleiro desta femme fatale esperta e cruel. A imagem de seu lado feminino presente neste poema, termina de forma tão negativa quanto começou, servindo como um objeto de adoração sexual. Por fim, conclui dizendo que seu desejo de ser mulher serve também para humilhá-lo, "para poder me recusar", mostrando uma atitude autodestrutiva, cruel consigo próprio. Este poema tem uma ambientação moderna, ao contrário de "Salomé" que tem um clima ligado ao Oriente e ao passado histórico em que viveu a personagem feminina original. Há referência aos cafés parisienses e ao pó-de-arroz, que representam um espaço e um objeto bem próprios da modernidade. Ao mesmo tempo em que, contudo, nota-se que o mito de Salomé continua presente em sua essência, bem como o arquétipo da femme fatale que, como mostra Morão (2001), inicia-se com Salomé e funde-se com outras figuras femininas. Como Meletinsky (1999) afirma sobre os arquétipos literários, mesmo que eles sofram alterações ao longo do tempo, eles guardam o seu significado original, por isso que mesmo sem fazer referência a Salomé ou a outra personagem que possa representar o feminino perverso, a noção fundamental desse arquétipo continua e mesma em "Feminina".

\section{Eros e Thanatos nas narrativas de Mário de Sá-Carneiro}

Dito isso sobre a presença do mito de Eros e Thanatos na lírica de Sá-Carneiro é o momento de analisarmos de que forma este mito aparece em suas narrativas. Frye afirma 
que o levantamento dos mitos nas narrativas também é relevante para a sua interpretação literária: "Em obras com personagens próprios, como peças e romances, a mesma análise psicológica pode ser estendida à interação entre os personagens, [...]" (FRYE, 2000, p. 17). A forma como os mitos interferem na interação das personagens dá uma ideia de como a "realidade" é posta na obra. Além disso, a maneira como as personagens são construídas também a partir dessas relações e das interpretações trazidas pelos mitos revela de que forma a "pessoa" - segundo a terminologia de Michel Zéraffa (2010) - é concebida dentro do universo da narrativa estudada. Sendo assim, a interação entre as personagens, construída a partir da forma como os mitos aparecem, além da forma como a "pessoa" é concebida dentro da realidade posta na obra, ajudam a compor um quadro da visão de mundo do autor.

O termo "pessoa" colocado no parágrafo anterior refere-se ao conceito utilizado por Michel Zéraffa (2010), e significa a forma como o romancista percebe e concebe o homem e a sua presença de mundo em uma narrativa. Toda personagem de uma narrativa nos remete a uma concepção de "pessoa", isto é, ao construir uma personagem o autor também está construindo uma forma de ver o ser humano e, também, uma visão de mundo. Assim,

[...] um ponto de vista e uma técnica romanescas procedem sempre de uma concepção da pessoa, e esta concepção, se é totalizante, jamais é total: o romancista usa de sua onisciência para privilegiar um aspecto do homem e da vida humana que ele julga ser dominante ou essencial à sua época. (ZÉRAFFA, 2010, p. 40)

Por isso, todas as técnicas de narração, desde a forma como se conta a história até a maneira como as personagens são construídas e interagem entre si, revelam o ponto de vista de um autor. Essa concepção jamais será "total”, porque não dará conta de todas as formas de se narrar, tampouco das técnicas de narração existentes. Por exemplo, não há como uma narrativa ter um tom mais "realista", buscando uma roupagem mais próxima das teorias marxistas e, ao mesmo tempo, apresentar outra faceta mais ligada ao surrealismo, ou ao fantástico no sentido mais lato. O autor deve escolher uma forma de narrar, de conceber o universo da sua história e também uma maneira de construir e apresentar suas personagens. Esse universo interno é "totalizante" porque é construído de forma a que se apresente coeso e coerente, do início ao fim da narrativa de uma mesma forma. As escolhas feitas a partir desse ponto de vista revelam a concepção de "pessoa" - termo que usaremos nesta pesquisa a partir de agora sempre com o significado construído por Zéraffa - e também uma visão de mundo do autor relacionada a ela.

É certo que esse olhar nunca é livre de inconsistências, ainda mais para um autor moderno, como Sá-Carneiro, que não vai se ater a uma forma "realista" de narrar. Sá-Carneiro em suas narrativas construía um universo em que as interpretações de viés marxista possivelmente não sejam as que melhor possam contribuir para a sua interpretação. Nas narrativas deste autor, pouco se explora sobre as relações entre as classes sociais e a "realidade" propriamente dita. Ele, juntamente com Fernando Pessoa e os outros colegas de Orpheu, experimentou novas possibilidades e novas vanguardas artísticas, mostrando um desejo similar ao de suas personagens, o de buscar uma arte superior e inovadora.

Segundo Walter Benjamin (1996) o período entendido como Modernidade foi uma época em que as experiências eram muito pouco significativas para os indivíduos, principalmente os mais sensíveis como os artistas. $\mathrm{O}$ ambiente para esses artistas, que é representado da mesma forma para as protagonistas de Sá-Carneiro, não traz respostas 
significativas para esses indivíduos, que não enxergam respostas profundas e relevantes no cientificismo - representado, por exemplo, pelo behaviorismo, determinismo e positivismo em vigor na época - e nem no misticismo de cunho decadentista.

Além disso, a Modernidade não é um período particularmente confortável para o artista, que não enxerga um lugar para si dentro do estado de coisas colocado pelo Capitalismo e por esse esvaziamento das experiências. Nesse contexto, segundo Octavio Paz (1982) não há lugar para a poesia (e podemos acrescentar, para a arte em geral), a burguesia não tem interesses artísticos, nem as massas contemporâneas. Assim, pelo que percebemos, dentro da visão de mundo do autor havia poucas saídas possíveis para as suas protagonistas, e entre elas notamos o refúgio em uma espécie de dandismo heróico, à maneira de Baudelaire e na estetização da vida. Dessa forma, as narrativas de Sá-Carneiro expressam essa insatisfação com a sociedade burguesa e sua reificação, por isso o tema frequentemente encontrado nelas é a busca de uma arte superior pelas protagonistas que, na maioria das vezes são concebidos como artistas geniais.

Por isso, a afirmação de Carpinteiro (1960) de que o amor em Sá-Carneiro só pode ser resolvido em morte, a partir da presença do mito de Eros e Thanatos precisa ser contextualizada, para que possamos extrair desse mito uma contribuição para a formação de uma visão de mundo. O amor só pode ter esse desfecho nas narrativas estudadas porque parte de uma visão dicotômica da mulher. Como apontado por Morão (2001), os homens do fim de século XIX concebiam a mulher basicamente de duas formas: ou ela é a esposa burguesa e comportada, ou é a femme fatale. Veremos, a seguir, alguns exemplos da forma como o mito de Eros e Thanatos aparece nas narrativas de Sá-Carneiro, e poderemos ver como o amor torna-se algo irrealizável também por causa dessa dicotomia. As protagonistas das narrativas não poderiam ser felizes ao lado de mulheres burguesas, uma vez que desejavam algo mais significativo que o cotidiano banalizado pela reificação provocada pela Modernidade; tampouco poderia ser felizes ao lado de mulheres fatais.

Northrop Frye (1973) diferencia duas formas de o mito aparecer em uma obra literária, o mito pode ser deslocado ou não deslocado. O mito não deslocado trata de deuses e demônios, do que ele chama "sociedade dos deuses" (FRYE, 1973, p. 143), isto é, do mito em sua forma original, que traz as personagens mitológicas da forma como são tradicionalmente conhecidas. E há o que ele chama de deslocamento do mito: "Por deslocamento me refiro às técnicas que um escritor usa para tornar sua história verossímil, logicamente motivada ou moralmente aceitável - semelhante à vida, em resumo." (FRYE, 2000, p. 44). O deslocamento nada mais é que uma espécie de adequação do mito à realidade, ao universo em que o autor situa a sua obra. $\mathrm{Na}$ épica antiga podia-se ter um embate entre deuses e mortais, os heróis podiam realizar feitos sobre-humanos, isso fazia parte da realidade daquelas narrativas. Com o passar do tempo, e das escolas literárias, houve um maior tom de realismo nas obras literárias e, mesmo na literatura fantástica, o mito sofre esse deslocamento, essa adequação. Mas mesmo que o mito esteja de certa forma disfarçado pelo deslocamento, podemos encontrá-lo num nível mais profundo da narrativa.

A primeira narrativa a ser analisada neste artigo faz parte das primeiras obras em prosa de Sá-Carneiro, que faz parte de Princípio: trata-se de "Loucura...". Ela é construída com um narrador em $3^{\mathrm{a}}$ pessoa, que é personagem e amigo da protagonista, o escultor Raul Vilar, que relata a comoção causada pelo seu suicídio. Aliás, é muito comum as personagens principais das histórias de Sá-Carneiro serem artistas, sempre muito bem de vida e sem problemas financeiros. Muitas de suas personagens são dandys, mas de qualquer forma, mesmo as que não são explicitamente assim sempre são pessoas muito bem resolvidas financeiramente. 
Nessa narrativa, Raul, ao perceber que a passagem do tempo destruirá a beleza de sua esposa, resolve matá-la, para eternizar na morte essa beleza. Há, ainda, além dessa questão do amor ligado à morte, a da loucura e da passagem do tempo. Podemos notar o deslocamento do mito de Eros e Thanatos para o ambiente do começo de século XX, um escultor que, dominado pela sua insanidade, sua obsessão mórbida, acredita que a maior prova de amor que poderia dar a sua esposa seria matá-la, para perpetuar aquele momento de sua vida. Curiosamente, antes de se casar, ele despreza o modelo de família burguesa, cujo centro é o casamento, mas apaixona-se por Marcela, que se caracteriza por ser uma típica representante da burguesia portuguesa.

A certa altura da narrativa, Raul faz uma confidência ao narrador, seu amigo, que além de revelar sua loucura, desvenda ideias inusitadas que podem ser associadas ao Decadentismo, na sua forma antiburguesa de ver o mundo:

Se Marcela pensasse como eu, podíamos ser tão felizes... tão felizes... Morrer nos seus braços... a beijar-lhe a boca... a morder-lhe os seios... Morrer com ela... com os nossos corpos entrelaçados... Num êxtase supremo dos sentidos... da alma prestes a evolar-se... Ah! como seria bom... Morreríamos romanticamente, numa noite de luar, rodeados de flores... de orquídeas... de rosas... de muitas rosas... Gostava tanto de morrer assim... tanto... Para morrer só, falta-me coragem... tenho medo... Mas ela não pensa como eu... ela pensa como todos... Ela gosta da vida... da vida... da vida... da vida!... (SÁ-CARNEIRO, 1995, p. 284).

Percebemos que a loucura de Raul o faz desejar uma situação inusitada, considerada mórbida pelo bom senso. Um suicídio conjunto com sua esposa seria para ele a realização de um sonho, seria um momento supremo, o "além" almejado, superior aos instantes comuns de uma vida normal. Mas Raul se mostra desiludido, uma vez que sua esposa não deseja o mesmo que ele, Marcela "ama a vida", isto é, ela não tem esse desejo de morrer nos braços do amado, quer viver uma vida normal, levar uma existência como as outras pessoas. Para ela, esse ato seria uma loucura, algo negativo, já para Raul, a mesma situação seria um momento de amor sublime, superior, elevado.

Há uma ligação interessante entre essa narrativa e outra que influenciou fortemente os simbolistas, decadentistas e também outros escritores da época: a obra Axel, de Villiers de L'Isle-Adam, última obra desse autor, e que reflete o seu idealismo. Conforme defende Edmund Wilson em sua obra $O$ castelo de Axel, nesta narrativa do escritor francês também há o mito de Eros e Thanatos, há uma relação entre amor e morte, uma vez que as protagonistas, amantes, se suicidam para "guardar" um momento sublime de amor, que o tempo e a vida comum e cotidiana tenderiam a destruir:

Viver? Não. Nossa existência está completa, e sua taça transborda. Que ampulheta contará as horas desta noite! O futuro?... Sara, crê nestas palavras: nós acabamos de esgotá-lo. Todas as realidades, amanhã que serão elas em comparação às miragens que acabamos de viver? [...] Reconhece-o, Sara: nós destruímos, nos nossos estranhos corações, o amor pela vida - e é e é justamente na REALIDADE que nos transformamos em nossas almas! Aceitar, a partir de agora, viver, não seria mias que um sacrilégio contra nós mesmos. Viver? Nossos criados farão isso por nós... (L'ISLE-ADAM, 2005, p. 198-199).

Há certa interdiscursividade entre os dois textos, sendo que a ideologia presente em Axel aparece relativizada na narrativa de Sá-Carneiro. Em ambos há a noção de que um momento de amor sublime entre os amantes é algo único, altivo, que não pode mais se 
repetir ao longo da vida. Segundo Wilson (2004), em Axel, na opinião dos protagonistas, o cotidiano, a existência diária e comum destruiria aquele instante genial, superior. Por isso o desgosto, tanto de Axel quanto de Raul pela vida, que deve ser experimentada pelas pessoas comuns, pelos criados na narrativa de Villiers de L'Isle-Adam, ou pela burguesia, em Sá-Carneiro. Há, contudo, uma diferença importante. Em Axel, a proposta do amante é aceita e ambos se suicidam, sendo que, nesta obra, isso não é indício de loucura, mas uma constatação de que a vida comum e cotidiana destruiria algo construído pelos dois em um momento sublime, a existência do dia a dia iria desgastar esse instante elevado, e chegaria mesmo a ser, nas palavras da protagonista, um verdadeiro sacrilégio. E a amada de Axel concorda com tudo isso, por pensar da mesma forma. Em Axel, Eros e Thanatos aparece como um mito redentor, a morte serviria para sublimar o amor do casal.

Na narrativa de Sá-Carneiro, Marcela não compartilha dos mesmos ideais de Raul, não possui esse desejo de algo maior, por não reconhecer no suicídio conjunto numa noite de amor, um gesto grandioso, como Raul o faz. Por ser burguesa e não possuir a loucura do marido, que na visão de Sá-carneiro, funciona como uma força que leva a um "além", a uma realidade superior, ela se nega a cometer tal ato. Assim, em "Loucura..." o mito de Eros e Thanatos já não funciona como redentor, mas sim como um elemento que leva ao final trágico para o casal. De qualquer forma, reconhecemos em "Loucura..." uma ideologia partilhada por Sá-Carneiro muito similar àquela presente em Axel, de Villiers de L'Isle-Adam, uma espécie de aversão pela vida comum, o desejo de alcançar sensações sublimes por meio de uma vida inusitada, ao mesmo tempo em que se deseja guardar, manter de alguma forma um momento único, iluminado, que seria banalizado pela vida cotidiana.

Apesar da similaridade entre as narrativas, podemos perceber que o mito de Eros e Thanatos funciona de forma diferente nas duas narrativas, na forma como ele interfere na interação das personagens. Mas não há nada de estranho nesse fato. Northrop Frye fala em "alegorização" do mito, que seria fazer uma interpretação fixa, cristalizada do mito, sempre que ele aparecer em uma obra. Segundo ele, essa metodologia é errônea, uma vez que o mito deslocado em uma obra pode levar a significados distintos do original:

A alegorização do mito é empecida pela presunção de que a explicação "é" o que o mito "significa". Sendo o mito uma estrutura centrípeta de sentido, podemos fazê-lo significar um número indefinido de coisas, e é mais frutuoso estudar o que de fato os mitos têm sido levados a significar. (FRYE, 1973, p. 333)

Portanto, o mito de Eros e Thanatos, deslocado para as narrativas de Mário de Sá-Carneiro, não deve ser interpretado, integralmente da mesma forma como ele foi concebido em Axel. No universo de "Loucura..." e de outras narrativas de Sá-Carneiro, Thanatos prevalece sobre Eros, a obsessão decadentista vence o sentimento calmo e positivo, a personagem não vai encontrar a amada que pensa como ele, e seu final será, inevitavelmente, trágico. $\mathrm{O}$ artista moderno, mesmo sendo superior aos demais não consegue fugir de seu destino trágico, a partir da visão de mundo de Sá-Carneiro. Por isso, o mito de Eros e Thanatos aparece deslocado aqui como uma fatalidade impossível de ser evitada. Uma vez que Raul - personagem que representa a "pessoa", segundo a terminologia de Zéraffa (2010), dos artistas - não pode viver o amor burguês, seu amor só pode ser "resolvido" na morte, como explica Carpinteiro (1960).

Outra narrativa em que pode ser encontrado o mito de Eros e Thanatos é "Incesto", também de Princípio. O narrador é em terceira pessoa, mas desta vez, ao contrário de 
"Loucura...", ele não é uma personagem, é um narrador onisciente. O protagonista, Luís de Monforte, é um autor dramático, na faixa etária dos quarenta anos. Percebemos de início que a protagonista tem a mesma característica de muitas protagonistas das narrativas de Sá-Carneiro, é um artista, um escritor, que não possui dificuldades financeiras, ao contrário, vive muito bem e pertence às classes mais altas da sociedade. Ele possui uma filha, fruto de um romance de sua mocidade, com uma mulher que desapareceu, e teve a tarefa de criá-la sozinho. A mãe, Júlia, é descrita no início da narrativa como tendo traços bem ao estilo das mulheres das narrativas decadentistas: "[...] perversa e linda, desaparecera no turbilhão esfacelante duma vida arrebatadamente louca, tragicamente agitada" (SÁ-CARNEIRO, 1995, p. 302). Ela teve uma existência trágica, uma vida desregrada e agitada, era linda, mas perversa e desapareceu sem deixar vestígios ou explicações. Temos novamente, como em "Loucura..." o arquétipo mais comum das narrativas ao estilo decadentista de Sá-Carneiro: a femme fatale, que levará o protagonista Luís de Monforte a se deparar com Eros e Thanatos.

Apesar de aparecer pouco na narrativa, a personagem Júlia é muito importante para a construção da visão de mundo do autor, uma vez que ela representa o arquétipo da mulher fatal e, também por isso, é uma personagem muito significativa e reveladora. A seguir temos uma descrição de Júlia:

Duma beleza misteriosa - cabeleira de fogo, olhos de infinito - esboçava-se-lhe nos lábios úmidos o sorriso enigmático da Jucunda. Do seu corpo flexível de estátua grega, admiravelmente musculada, desprendia-se um aroma estranho que lhe poetizava a carne em pedra, audaciosa e mal escondida. Atraía e afugentava ao mesmo tempo essa mistura singular de inferno e céu; pressentia-se sem saber por quê, nessa mulher frágil, todo um poema brutal de amor ardente, de voluptuosidade e de sangue. (SÁ-CARNEIRO, 1995, p. 303).

Assim, a descrição de Júlia se refere bem a uma femme fatale, uma bela mulher, com corpo escultural, e o sorriso enigmático da Gioconda, de Leonardo da Vinci, mas perigosa. É descrita como uma mulher que atrai e afugenta ao mesmo tempo, uma mistura de “inferno e céu”. O seu amor é ardente, intenso, mas ligado ao mórbido, à voluptuosidade, à obsessão e à violência. É uma mulher que desperta uma paixão avassaladora, mas que é um sentimento que se torna paradoxal, uma vez que traz conseqüências ruins para Luís. É uma boa representante da relação entre a Eros e Thanatos, se fizermos uma leitura não alegorizada e adequada desse mito deslocado.

É um sentimento nos moldes decadentistas, ligando o amor à obsessão, à violência. E foi dessa forma que Júlia se comportou, no seu relacionamento com Luís, uma vez que, ao nascer a filha dos dois, a mãe abandona o lar. O nascimento de Leonor, que seria um laço a mais no relacionamento descrito como forte e feliz pelo narrador, foi um motivo a mais para Júlia fugir. Ela agiu como uma mulher fatal, uma vez que se entregou ao dramaturgo, se envolveu fortemente com ele, e, no momento que seria o mais feliz de todos e que selaria definitivamente os laços do matrimônio - o nascimento de Leonor - e que seria o auge do relacionamento dos dois, Júlia foge com outro homem. Isso deixou Luís desesperado e humilhado perante a sociedade.

Ao final da narrativa, depois de ter passado muito tempo atormentado pela loucura e pela sensação estranha de ter cometido uma espécie de incesto com a filha - por ter-se casado com Magda, que era muito parecida com ela - Luís de Monforte encontra uma solução para o seu martírio: o suicídio. Pelo menos é isso que o final da narrativa parece indicar, porque se trata de um trecho bastante simbólico e lírico. Mais uma vez, a solução para o amor - desta vez um amor criminoso para o protagonista - foi a morte. 
Em "Ressurreição", que faz parte de Céu em fogo, a narrativa, em $3^{\text {a }}$ pessoa, conta a história de Inácio de Gouveia, que se enquadra no perfil da maioria das protagonistas de Sá-Carneiro, é um artista, um escritor e, por isso, um ser superior aos demais, mais sensível, mais sofisticado. Mais uma vez, como em "Loucura..." e "Incesto", temos a protagonista afetada pela insanidade, como é possível perceber desde o começo da narrativa. Ele se envolve com uma moça simples e bem menos intelectualizada que ele, Paulette, e também com um ator, Etienne, com quem conseguia trocar ideias artísticas e mantinha um romance reprimido. Há uma confusão sentimental por parte de Inácio, que não consegue diferenciar o que sentia por Paulette, do que sentia por Etienne. Aliás, para Inácio, Paulette funciona como uma femme fatale, que o confunde e lhe traz sentimentos negativos. Certa vez, quando soube que Paulette estava envolvida com um dançarino mexicano, e envolvida com drogas e sexo, em um relacionamento autodestrutivo, Inácio sentiu certa excitação sexual por causa disso. Quando soube da morte de Paulette, sente uma excitação sexual por causa disso e passa a desejar mais claramente Etienne:

Com efeito, ao darem-lhe a notícia da morte de Paulette, sentira como que um espasmo a esvaí-lo roxamente... “-Tivera o gênio de arder até o fim - morrera!” E esta idéia excitara-o como se lhe viessem contar que ela hoje dançava, de sexo nu, num grande teatro vermelho... A morte da rapariga parecera-lhe sempre uma última audácia, um último requinte - mais um deboche de capricho platinado... Eis pelo que, decerto, o romancista vivera os dias imediatos numa longa excitação sexual, nevoadamente - como nunca se lhe frisando o seu enternecimento por Etienne, em desejos quase decisivos de o beijar, para melhor exprimir todo o seu carinho... (SÁ-CARNEIRO, 1995, p. 580).

O mito de Eros e Thanatos aparece aqui como o reflexo de um indivíduo confuso emocionalmente, sendo que a morte traz uma espécie de satisfação, um aumento do sentimento e do desejo de Inácio. Como nas narrativas anteriores, há características decadentistas como relacionamentos destrutivos e doentios, além da presença do mito de Salomé e do arquétipo da femme fatale. Há o amor da protagonista por Paulette que, ao que tudo indica, não compartilhava esse sentimento por Inácio. Contudo, é a morte da atriz que possibilita a aproximação de Inácio com Etienne, e o amor entre os dois. Já havia um forte sentimento entre eles, mas parece que a morte de Paulette intensifica o sentimento entre os amigos. Mas, com certeza, é a morte de Paulette que torna possível a sua "ressurreição", o instante sublime que ocorre pela união dos dois amigos. Ela pouco aparece na história, e não tem muitas ações dentro do enredo, - o que comprova a afirmação de Maria Aliete Galhoz, de que as mulheres nas narrativas de Sá-Carneiro têm um papel secundário:

Eros leva a Thanatos nessas novelas [...] por incompletude num desejo de completude que avassala desmedidamente os "heróis" masculinos. [...] Nessa avidez e nessa consumição, a mulher funciona mais como um objecto do desejo masculino, partenaire consentiente ou tentadora, ou substituta do interdito, que o incesto é translato a um não interdito (o "crime" está na semelhança) e cessa, pelo suicídio, quando o protagonista consciencializa absolutamente a sua fixação pelo proibido. [...] Mas é Thanatos que rege, obscuramente até certo ponto para o autor, toda a obra de Mário de Sá-Carneiro. [...] que procura efeitos literários através da expressão do bizarro, do anômalo, do sombrio nas profundidades psíquicas dos homens, pois que, no seu quadro narrativo, a mulher comporta-se, só o homem age. (GALHOZ, 1990, p. 50-51).

Apesar de ser a femme fatale, o que poderia lhe dar um lugar de destaque, como ocorre em muitas histórias decadentistas, a personagem Paulette funciona apenas como 
um "instrumento", um ser que foi ressuscitado, uma vez que deveria haver alguém a desempenhar este papel, para que Inácio atingisse a sua busca, o seu sonho. Esse papel secundário das mulheres nas narrativas de Sá-Carneiro parece refletir o esquema social da época e a mentalidade masculina, em que o amor é formatado a partir da dicotomia entre a esposa comportada e a mulher fatal.

Nas três narrativas apontadas até aqui, a questão da loucura está bastante presente também, compondo a mediação da relação entre o amor e a morte das protagonistas com as mulheres. Por isso, o estilo de vida requintado e distante da realidade, aliado à loucura, fazem com que o amor, nessas narrativas, só possa ser resolvido em morte, como já vimos anteriormente. Isso ajuda a tornar trágicas essas narrativas, embora em "Ressurreição" os traços desse mythos - usando a terminologia da crítica arquetípica de Northrop Frye (1973) - não sejam tão fortes quanto nas outras narrativas. Se tomarmos o termo "tragédia" num sentido mais amplo, como propõe Frye, notaremos que essas protagonistas têm uma existência complicada pela própria vivência do artista moderno, com todas as suas dificuldades.

Além das três narrativas apontadas, podemos encontrar o mito de Eros e Thanatos em outras de Mário de Sá-Carneiro, não sendo o objetivo deste artigo abranger todas elas, mas algumas principais para mostrar a relevância do estudo deste mito na obre de SáCarneiro. Em "O fixador de instantes, a protagonista, em certo momento, se gaba de ter conseguido "fixar" alguns instantes, que seria como se ele pudesse manter um momento especial que ele viveu, de alguma forma, guardado para si: "O momento dourado, eu posso palpá-lo, revê-lo, tornar a beijá-lo em chama, [...] Eu, se perdi as almas, tenho os corpos para mais frisantemente as recordar. Embalsamei o instante" (SÁ-CARNEIRO, 1995, p. 531). Essa noção de guardar um momento especial, sublime, dialoga com a ideia presente em Axel, de que existem momentos que não podem ser medidos pelo tempo cronológico, ou pela racionalidade comum, burguesa: "Que ampulheta poderá contar as horas desta noite?" (L'ISLE-ADAM, 2005, p. 198). A vida comum destruiria o momento sublime vivido pelo casal de Axel, por isso Eros e Thanatos, no caso da narrativa de Villiers de L'Isle-Adam, estão em harmonia, assim o desejo do casal pelo suicídio. Isso não ocorre em "Loucura..." como vimos e também não ocorre em "O fixador de instantes", em que apenas as protagonistas desejam a morte. No caso desta última, apenas a morte da mulher amada seria concretizada, para que a protagonista "guardasse" esse instante para si.

Nesta narrativa, temos a presença de uma dançarina caracterizada como uma femme fatale, que nos remete novamente ao mito de Salomé. Esse trecho, em que a protagonista se encontra com sua amada e vítima ao mesmo tempo, tem um forte teor lírico, e a descrição da cena lembra muito o vocabulário simbolista de alguns de seus poemas:

Ebânicas, as tranças tinham-se-lhe desprendido; e era já só perversão e loucura a grande viciosa, quando, ao arquear-se sobre a cisterna alucinante, morta num êxtase - os próprios seios lhe golfaram nus, expectrais de roxidão, heráldicos de crime....

E quando por último caíram sobre ela, a esmagá-la, os sons finais da partitura, que os tambores fechavam sobre a fera - eu tive medo, ah!, sim, medo, que se não erguesse mais, consumado o poema, morta do amor, morta do desejo, que em mim suscitara, ou - pelo menos - morta de amor de si mesma...(SÁ-CARNEIRO, 1995, p. 534-535)

Assim, a protagonista crava um punhal no peito da dançarina, para que pudesse manter esse momento, e a própria dançarina, com ele: “Glória! Glória! Tenho-a para sempre !" (SÁ-CARNEIRO, 1995, p. 537). Há um desejo de transcendência por parte da protagonista que, por meio da morte da amada, conseguiria alcançar algo significativo para a sua 
existência. Para Seabra Pereira (1975), o artista decadentista busca uma forma de transcendência, uma explicação metafísica para as coisas que o rodeiam, mas não a encontra. Nesta narrativa, então, Eros e Thanatos aparecem como uma forma de possibilitar uma experiência sublime para a protagonista, apesar da crueldade e perversidade de seu ato.

Por fim, resta verificarmos como Eros e Thanatos aparecem na mais bem realizada narrativa de Sá-Carneiro: A Confissão de Lúcio. Há elementos do fantástico bastante relevantes para a interpretação da narrativa, inclusive a ideia de que Marta foi uma criação de Ricardo, para que ele pudesse amar Lúcio, uma criação que era parte dele mesmo. Antes de matar Marta, - e consequentemente morrer, visto que ela era uma parte dele mesmo Ricardo se explica ao amigo, mostra o porquê de sua criação:

Ela é só minha - entendes? - é só minha!... Compreendemo-nos tanto, que Marta é como se fora a minha própria alma. Pensamos da mesma maneira; igualmente sentimos. Somos nós-dois... Ah! e desde essa noite eu soube, em glória soube, vibrar dentro de mim o teu afeto - retribuir-to: mandei-A ser tua! Mas, estreitando-te ela, era eu próprio quem te estreitava... Satisfiz a minha ternura: Venci. E ao possuí-la, eu sentia, tinha nela, a amizade que te deveria dedicar - como os outros sentem na alma as suas afeições. Na hora em que a achei, tu ouves?, foi como se a minha alma, sendo sexualizada, se tivesse materializado. E só com o espírito te possuí, materialmente! Eis o meu triunfo... Triunfo inigualável! Grandioso segredo!... (SÁ-CARNEIRO, 1995, p. 410-411)

Assim, Marta foi uma criação de Ricardo, frente a sua insatisfação existencial e também para que ele se relacionasse com o amigo Lúcio. A partir do momento em que Marta passou a desagradar Lúcio, por causa de seus outros amantes, Ricardo quis lhe dar um fim, para que sua relação com o amigo continuasse. Mas como Marta era uma criação que fazia parte dele mesmo, de sua identidade fragmentada, a morte dela foi também o fim de Ricardo e, consequentemente, do amor que o unia a Lúcio. Nesta narrativa, Thanatos seria uma saída que possibilitaria a continuidade de Eros, a morte de Marta seria a solução que permitiria o amor entre os amigos.

\section{Considerações finais}

De forma geral, podemos apontar algumas contribuições que a análise da presença do mito de Eros e Thanatos pode acrescentar de relevante na interpretação dos poemas e das narrativas de Mário de Sá-carneiro.

$\mathrm{Na}$ lírica, esse mito está associado com o arquétipo da femme fatale, a partir do mito de Salomé. Essa mulher fatal, que na obra de Sá-Carneiro possui raízes simbolistas e decadentistas, aponta para um fator de perdição para o eu-lírico, de algo bastante negativo para ele. Como aponta Seabra Pereira (1975), a figura feminina aparece não como um elemento de redenção para o eu-lírico, algo bastante comum no Romantismo, por exemplo, mas sim como uma figura que irradia encantamento e lascívia, representando uma atração fatal, que subjuga o sujeito masculino. A femme fatale representa formas pervertidas de sexualidade e gera uma tensão irresolúvel. Nos poemas de Sá-Carneiro, essa figura feminina representa uma parte do próprio eu-lírico, uma parcela negativa de sua identidade fragmentada.

Nas narrativas, Eros e Thanatos estão em inevitável ligação, uma vez que o amor em suas narrativas só pode ser resolvido com a morte. Seja pela loucura das protagonistas que almejam um instante sublime, como Raul e a protagonista sem nome de "O fixador de instantes”, seja pela própria perdição que essa figura feminina gera nessas personagens. 
Percebemos nesta forma de ver o mundo de Mário de Sá-Carneiro e na maneira como ele constrói o universo de suas narrativas, uma maneira simplista e imatura de conceber o amor, e notamos uma dicotomia a respeito das mulheres, própria do século XIX: ou ela é a esposa burguesa e comportada, ou é a femme fatale, um arquétipo que trará ruína e destruição para as protagonistas. Há um tom trágico nessas narrativas, em que as protagonistas tinham de escolher entre duas opções insatisfatórias no campo amoroso: ou a mulher burguesa, que representa a banalidade e a reificação das relações de uma sociedade em que o artista não tem espaço, ou a femme fatale que leva à ruína. Em ambos os casos, seja qual for a escolha, o final para o amor sempre será trágico, o desfecho será em morte, inevitavelmente. Essa insatisfação e essas opções insatisfatórias remetem à situação dos artistas do Decadentismo ou, como Sá-Carneiro, um escritor de transição que possui uma parte de sua obra com muitas características desse movimento: uma sensação de incompletude, de angústias existenciais que não podem ser resolvidas, nem pelo misticismo de cunho decadentista, nem pelo cientificismo da Modernidade.

\section{Referências}

BENJAMIN, Walter. "Experiência e pobreza”. In: Obras escolhidas. Vol. 1. Magia e técnica, arte e política. São Paulo: Brasiliense, 1996.

CARPINTEIRO, Maria da Graça. A novela poética de Mário de Sá-Carneiro. Lisboa: Centro de estudos filológicos, 1960.

CASSIRER, Ernst. Linguagem e mito. Trad. J. Guinsburg, Miriam Schnaiderman. São Paulo: Perspectiva, 2009.

FRYE, Northrop. Anatomia da crítica. São Paulo: Cultrix, 1973. . Fábulas de identidade. São Paulo: Nova Alexandria. 2000.

GALHOZ, Maria Aliete. "Thanatos, Eros e Ícaro. As leis profundas (já) das primeiras narrativas ficcionais de Mário de Sá-Carneiro (textos de 1908 a 1912)" / Maria Aliete Galhoz. In: Revista Colóquio/Letras. Ensaio, n. ${ }^{\circ}$ 117/118, Set. 1990, p. 47-53.

JUNG, Carl G. O homem e seus símbolos. 3 ed. Rio de Janeiro: Nova fronteira, 1964. L'ISLE-ADAM, Villiers de. Axël. Tradução de Sandra M. Stroparo. Curitiba: Editora da UFPR, 2005.

MARTINS, Fernando Cabral. O modernismo em Mário de Sá-Carneiro. Lisboa: Editorial Estampa, 1994.

MELETINSKI, Eleazar M. Os arquétipos literários. Cotia: Ateliê Editorial, 1999.

MORÃO, Paula. Salomé e outros mitos. Lisboa: Cosmos, 2001.

PAIXÃO, Fernando. Narciso em sacrifício. Cotia: Ateliê Editorial, 2003.

PAZ, Octavio. O arco e a lira. Tradução de Olga Savary. Rio de Janeiro: Nova Fronteira, 1982.

PEREIRA, José Carlos Seabra. Decadentismo a simbolismo na poesia portuguesa.

Coimbra: Coimbra editora, 1975.

SÁ-CARNEIRO, Mário de. Poemas. Ed. Teresa Sobral Cunha. São Paulo: Companhia das Letras, 2004.

Obra completa. Rio de janeiro: Nova Aguilar, 1995.

WILSON, Edmund. O castelo de Axel. Trad. José Paulo Paes. São Paulo: Companhia das Letras, 2004.

WOLL, Dieter. Realidade e Idealidade na lírica de Sá-Carneiro. Lisboa: Delfos, 1968. ZÉRAFFA, Michel. Pessoa e personagem: o romanesco dos anos 1920 aos anos 1950. Trad. Luiz João Gaia e J. Guinsburg). São Paulo: Perspectiva, 2010; 